\title{
Soil bacterial and fungal community successions under the stress of chlorpyrifos application and molecular characterization of chlorpyrifos-degrading isolates using ERIC-PCR*
}

\author{
Lie-zhong CHEN ${ }^{\dagger 1,2}$, Yan-li $\mathrm{LI}^{2}$, Yun-long YU ${ }^{1}$ \\ ( ${ }^{1}$ Department of Plant Protection, College of Agriculture \& Biotechnology, Zhejiang University, Hangzhou 310029, China) \\ ( ${ }^{2}$ State Key Laboratory Breeding Base for Zhejiang Sustainable Pest and Disease Control, Institute of Plant Protection and Microbiology, \\ Zhejiang Academy of Agricultural Sciences, Hangzhou 310021, China) \\ †E-mail: zwsclz@163.com
}

Received June 27, 2013; Revision accepted Jan. 7, 2014; Crosschecked Mar. 18, 2014

\begin{abstract}
Chlorpyrifos is a widely used insecticide in recent years, and it will produce adverse effects on soil when applied on crops or mixed with soil. In this study, nested polymerase chain reaction (PCR) and denaturing gradient gel electrophoresis (DGGE) were combined to explore the bacterial and fungal community successions in soil treated with 5 and $20 \mathrm{mg} / \mathrm{kg}$ of chlorpyrifos. Furthermore, isolates capable of efficiently decomposing chlorpyrifos were molecular-typed using enterobacterial repetitive intergenic consensus-PCR (ERIC-PCR). Under the experimental conditions, degradation of chlorpyrifos in soil was interpreted with the first-order kinetics, and the half-lives of chlorpyrifos at 5 and $20 \mathrm{mg} / \mathrm{kg}$ doses were calculated to be 8.25 and $8.29 \mathrm{~d}$, respectively. DGGE fingerprint and principal component analysis (PCA) indicated that the composition of the fungal community was obviously changed with the chlorpyrifos treatment, and that samples of chlorpyrifos treatment were significantly separated from those of the control from the beginning to the end. While for the bacterial community, chlorpyrifos-treated soil samples were apparently different in the first $30 \mathrm{~d}$ and recovered to a similar level of the control up until $60 \mathrm{~d}$, and the distance in the PCA between the chlorpyrifos-treated samples and the control was getting shorter through time and was finally clustered into one group. Together, our results demonstrated that the application of chlorpyrifos could affect the fungal community structure in a quick and lasting way, while only affecting the bacterial community in a temporary way. Finally, nine typical ERIC types of chlorpyrifos-degrading isolates were screened.
\end{abstract}

Key words: Denaturing gradient gel electrophoresis (DGGE), Bacterial community, Fungal community, Chlorpyrifosdegrading isolates, Enterobacterial repetitive intergenic consensus-PCR (ERIC-PCR) doi: $10.1631 /$ jzus.B1300175

Document code: A

CLC number: Q93-3

\section{Introduction}

Chlorpyrifos is a broad-spectrum moderately toxic organophosphorus insecticide. It is widely applied to prevent pests like stem borers, army worm,

\footnotetext{
* Project supported by the Zhejiang Provincial Key Technology Innovation Team (No. 2010R50028) and the Hangzhou Science and Technology Development Program (No. 20110232B11), China (C) Zhejiang University and Springer-Verlag Berlin Heidelberg 2014
}

coccid, and aphids. Whether sprayed on the crops or mixed with soil, eventually there will be a large number of chlorpyrifos entered into the soil environment. The half-life of chlorpyrifos in soil usually ranges from 60 to $120 \mathrm{~d}$, while sometimes less than two weeks, and sometimes greater than one year, depending on soil type, soil microorganisms, and climate conditions (Anwar et al., 2009). The residues of chlorpyrifos in soils may affect the stability of the soil microbial community and function (Kulkarni 
et al., 2000). Soil microorganisms participating in the decomposition and transformations of soil materials are important factors influencing the fertility of soil, thus they play an important role in the sustainable utilization of soil (Sebiomo et al., 2011). Interactions between chlorpyrifos and soil microorganisms, including microbial biomass carbon and nitrogen, microbial populations, microbial functional diversity, microbial respiration, enzymatic activities, and nitrogen cycling, have been widely studied (Sardar and Kole, 2005; Pandey and Singh, 2006; Fang et al., 2009; Xie et al., 2010). In addition, many strains capable of degrading chlorpyrifos have been isolated to amend the chlorpyrifos-polluted environment (Maya et al., 2011). However, the successions of soil bacterial and fungal community structures, which can truly reveal dynamic changes of microbes, have remained unknown. Furthermore, different chlorpyrifosdegrading isolates may exist in different soil environments.

Denaturing gradient gel electrophoresis (DGGE) originally developed in the 1980s (Muyzer et al., 1993) has been widely used in characterizations of soil bacterial and fungal communities. In DGGE, DNA fragments of the same length but of different sequences can be separated. DGGE profiles can visualize what constitute all the major microorganisms, and provide data for difference analysis in the tested samples. Although DGGE has numerous advantages, it cannot obtain functional strains for deep analysis and practical application. Traditional isolation of microbes will make up for the disadvantage and obtain a large number of cultural strains. Enterobacterial repetitive intergenic consensus (ERIC) (Sampaio et al., 2006) sequences are repetitive elements distributed along the bacterial chromosome of Gramnegative bacteria, at intergenic regions of polycistronic operons or flanking open reading frames. ERIC-polymerase chain reaction (PCR) relying on the amplification of genomic DNA fragments using different sets of primers complimentary to the short repetitive sequences has been observed with extremely good discriminatory index and reproducibility for molecular typing of microbes (Gillings and Holley, 1997; Yuan et al., 2010).

In this study, we aimed to reveal the response of soil bacterial and fungal community structures to chlorpyrifos applications, furthermore, to molecular characterize chlorpyrifos-degrading strains isolated from chlorpyrifos-contaminated soil by ERIC-PCR.

\section{Materials and methods}

\subsection{Chemicals and media}

Chlorpyrifos standard ( $\geq 99.5 \%$ ) was purchased from the Beijing Cubic Joint Institute of Chemical Technology, China. Acetone and petroleum ether $\left(60-90{ }^{\circ} \mathrm{C}\right)$ of analytical grade were purchased from the Changqing Chemical Co., Hangzhou, China. Commercial formulation of chlorpyrifos (Dursban, $48 \%$ ) was purchased from an agro-chemical store.

Mineral salt medium (MM) was constituted by $5.0 \mathrm{~g}$ of $\left(\mathrm{NH}_{4}\right)_{2} \mathrm{SO}_{4}, 1.0 \mathrm{~g}$ of $\mathrm{KH}_{2} \mathrm{PO}_{4}, 0.1 \mathrm{~g}$ of $\mathrm{NaCl}$, $0.5 \mathrm{~g}$ of $\mathrm{MgSO}_{4} \cdot 7 \mathrm{H}_{2} \mathrm{O}, 0.1 \mathrm{~g}$ of $\mathrm{CaCl}_{2}$, and $0.2 \mathrm{~g}$ of yeast extract in $1000 \mathrm{ml}$ distilled water. MM medium containing $40 \mathrm{mg} / \mathrm{L}$ of chlorpyrifos (MMC) as the single carbon source was used for enriching and screening chlorpyrifos-degrading strains. LuriaBertani medium, Czapek's agar medium, and Gause's agar medium were used to isolate the chlorpyrifosdegrading strains.

\subsection{Soil samples and soil treatment}

Soil was collected from experimental plots untreated with chlorpyrifos in the most recent five years located at Zhejiang Academy of Agricultural Sciences, Hangzhou, China. Soil samples taken from the top layer $(0-15 \mathrm{~cm})$ were mixed thoroughly and air-dried in the shade at room temperature, and then passed through a 2-mm sieve to remove any stones and debris. Its major characteristics were as follows: sand, $25.5 \%$; silt, $70.1 \%$; clay, $4.4 \%$; organic matter, $3.95 \%$; water holding capacity, $35.4 \%$; cationic exchange capacity, $10.6 \mathrm{cmol} / \mathrm{kg}$; total nitrogen, $0.14 \%$; and, $\mathrm{pH} 6.8$.

Soil samples $(5 \mathrm{~kg})$ were first pre-incubated in the dark for one week at $25^{\circ} \mathrm{C}$, and then chlorpyrifos commercial formulation following proper dilution with distilled water was added to give a final concentration of 5 and $20 \mathrm{mg} / \mathrm{kg}$ corresponding to the recommended dose and quadruple dose, respectively. Soil samples with the same amount of sterilized water without adding chlorpyrifos were used as the control, whose water content reached $10 \%$. Soil water content was maintained by the regular addition of distilled 
water every one week. Each treatment was conducted three times. At the intervals of 1, 7, 15, 30, 45 and $60 \mathrm{~d}$ after treatment, using five-spot sampling method, soil samples (about $500 \mathrm{~g}$ ) were obtained to determine the chlorpyrifos residues and to extract soil DNA for PCR-DGGE analysis. Furthermore, chlorpyrifostreated soil samples were used to isolate the potential strains capable of degrading chlorpyrifos at the end of the experiment.

\subsection{Determination of chlorpyrifos residues in soil}

The soil sample (20 g) was suspended in $140 \mathrm{ml}$ of acetone-petroleum ether mixture $(1: 1)$ in a $300-\mathrm{ml}$ Erlenmeyer flask on a rotary shaker under $30{ }^{\circ} \mathrm{C}$. After $2 \mathrm{~h}$, soil suspensions were then filtered through a filter paper, and the filter residue was rinsed three times with $20 \mathrm{ml}$ of acetone-petroleum ether mixture $(1: 1, \mathrm{v} / \mathrm{v})$. The filtrate (approximately $200 \mathrm{ml}$ ) was gathered in a 300-ml separatory funnel, and was further extracted three times with $50 \mathrm{ml}$ of $3 \%$ sodium sulfate to eliminate any acetone. The mixture of acetone and 3\% sodium sulfate was then extracted three times with $40 \mathrm{ml}$ of petroleum ether. Approximately $220 \mathrm{ml}$ of ethereal extract was collected in a 300-ml flat-bottom flask, dried by anhydrous sodium sulfate overnight, and then filtered. The filtrate was concentrated on a rotary evaporator till it was almost dry, and then ultrasound-dissolved with methanol. The final volume was made up to $10.0 \mathrm{ml}$ before gas chromatography-electron capture detector (GC-ECD) analysis. The residue of chlorpyrifos was determined using GC (GC-14B, Shimadzu, Japan) equipped with an ECD and an SPB-5 quarz capillary column (30 $\mathrm{m} \times 0.53 \mu \mathrm{mm} \times 0.10 \mu \mathrm{m}$ ). Operating conditions were as follows: detector, $280{ }^{\circ} \mathrm{C}$; injector port, $260{ }^{\circ} \mathrm{C}$; carrier gas $\left(\mathrm{N}_{2}\right)$ flow rate, $100 \mathrm{ml} / \mathrm{min}$; and, injection volume, $2 \mu \mathrm{l}$.

\subsection{DNA extraction}

The soil sample $(0.25 \mathrm{~g})$ was weighed to extract soil DNA using the soil DNA isolation kit (MoBio Laboratories, Solana Beach, CA). A microbe with a logarithmic growth phase was utilized to extract the microbial DNA via the ultraclean microbial DNA isolation kit (MoBio Laboratories, Solana Beach, CA). All the operations were carried out according to the manufacturer's instructions except that vortex mixing was used instead of a $2 \times 30 \mathrm{~s}$ bead-beating.

\subsection{PCR amplifications}

All PCRs were performed in an automated thermal cycler (Mastercycler, Eppendorf). Amplifications were carried out in a final volume of $50 \mu$ l containing $1 \times$ PCR buffer, $5 \mathrm{mmol} / \mathrm{L} \mathrm{MgCl}_{2}, 2 \mathrm{mmol} / \mathrm{L}$ dNTP's, $10 \mu \mathrm{mol} / \mathrm{L}$ each of primers, $2.5 \mathrm{U}$ TransStart Taq DNA polymerase from Transgene, and $1 \mu \mathrm{l}(\sim 10 \mathrm{ng})$ DNA template (chromosomal DNA or diluted PCR product).

ERIC-PCR analysis: ERIC (5'-AAG TAA GTG ACT GGG GTG AGC G-3') and ERIC-R (5'-ATG TAA GCT CCT GGG GAT TCA C-3') were applied to carry out molecular typing of chlorpyrifos-degrading strains. The thermal cycling scheme was heated to $95^{\circ} \mathrm{C}$ for $5 \mathrm{~min}$, then 30 cycles were run at $95^{\circ} \mathrm{C}$ for $40 \mathrm{~s}, 52{ }^{\circ} \mathrm{C}$ for $90 \mathrm{~s}$, and $65^{\circ} \mathrm{C}$ for $2 \mathrm{~min}$, and finally $65^{\circ} \mathrm{C}$ for $10 \mathrm{~min}$.

Fungal community analysis: ITS1f (5'-CTT GGT CAT TTA GAG GAA GTA A-3') and ITS1f-ge (5'-CGC CCG CCG CGC GCG GCG GGC GGG GCG GGG GCA CGG GGG GCT TGG TCA TTT AGA GGA AGT AA-3') were used for forward primers. ITS2 (5'-GCT GCG TTC TTC ATC GAT GC-3') and ITS4 (5'-TCC TCC GCT TAT TGA TAT GC-3') were used for reverse primers (Valášková and Baldrian, 2009). ITS1 region of fungal ribosomal DNA (rDNA) was amplified by nested PCR. With primer pair ITS1f/ITS4 and soil DNA as the template in the first round of PCR testing, amplified products of 700-900 bp comprising both ITS1 and ITS2 regions were obtained. With primer pair ITS1f-ge/ITS2 and the first-round PCR products, using the $10 \times$ dilution as a template in the second round of PCR testing, the ITS1 region about 200-300 bp was specifically amplified. The PCR included a 4-min denaturation step at $94{ }^{\circ} \mathrm{C}$ followed by 35 thermal cycles of $1 \mathrm{~min}$ at $94{ }^{\circ} \mathrm{C}, 30 \mathrm{~s}$ at $52^{\circ} \mathrm{C}$, and $1 \mathrm{~min}$ at $72{ }^{\circ} \mathrm{C}$, and a final extension at $72{ }^{\circ} \mathrm{C}$ for $10 \mathrm{~min}$.

Bacterial community analysis: $16 \mathrm{~S}$ rDNA PCR amplification was carried out using the soil DNA as the template and bacterial-specific primers, $8 \mathrm{~F}$ (5'-AGA GTT TGA TCC TGG CTC AG-3') and 1492R (5'-GGT TAC CTT GTT ACG ACT T-3'). A nested PCR for the $\mathrm{V} 3$ region was performed on the 8F/1492R PCR products using the 341F-gc (5'-CGC CCG CCG CGC GCG GCG GGC GGG GCG GGG GCA CGG GGG GCC TAC GGG AGG CAG 
CAG-3') and 518R (5'-ATT ACC GCG GCT GCT GG-3') primers (Valášková and Baldrian, 2009). The PCR included a 4-min denaturation step at $94{ }^{\circ} \mathrm{C}$ followed by 35 thermal cycles of $1 \mathrm{~min}$ at $94{ }^{\circ} \mathrm{C}, 30 \mathrm{~s}$ at $52{ }^{\circ} \mathrm{C}$, and $90 \mathrm{~s}$ at $72{ }^{\circ} \mathrm{C}$, and a final extension at $72{ }^{\circ} \mathrm{C}$ for $10 \mathrm{~min}$.

All the PCR products were resolved by $1.0 \%$ agarose gel electrophoresis and gel image was photographed with Tanon-2500 (Shanghai, China). The amplified products with a GC clamp were stored at $-20{ }^{\circ} \mathrm{C}$ for subsequent DGGE analysis.

\subsection{Analysis of PCR products by DGGE}

The DCode Universal Mutation Detection System (Bio-Rad, CA, USA) was used for DGGE analysis (Li et al., 2008). Approximately $20 \mu \mathrm{l}$ PCR products mixed with $10 \mu \mathrm{l} 3 \times$ loading buffer were loaded into a $8 \%(\mathrm{w} / \mathrm{v})$ polyacrylamide gel with a linear denaturing gradient from $40 \%$ to $55 \%$ for ITS1f-gc/ITS2 amplicons and $45 \%$ to $60 \%$ for $341 \mathrm{~F}-\mathrm{gc} / 518 \mathrm{R}$ amplicons $(100 \%$ denaturant corresponds to $40 \%$ formamide and $7 \mathrm{~mol} / \mathrm{L}$ urea). The gel was run for $15 \mathrm{~h}$ under $45 \mathrm{~V}$ in $1 \times$ Tris-acetate-EDTA (TAE) buffer at a constant temperature of $60^{\circ} \mathrm{C}$. After electrophoresis, the gel was stained for $20 \mathrm{~min}$ in an ethidium bromide solution $(0.5 \mathrm{mg} / \mathrm{L})$, and then destained for $30 \mathrm{~min}$ in distilled water. The DGGE profile image was digitally captured and saved in a Tanon 2500 gel image system.

\subsection{Enrichment and isolation of chlorpyrifos- degrading strains}

The soil samples $(5 \mathrm{~g})$ were first inoculated in 300-ml Erlenmeyer flasks containing $50 \mathrm{ml}$ MMC, and then incubated under the condition of $30^{\circ} \mathrm{C}$ on a shaker at $200 \mathrm{~g}$ for $4 \mathrm{~d}$. One milliliter culture broth was transferred to $50 \mathrm{ml}$ fresh MMC for another $4 \mathrm{~d}$, and this procedure was done four times. After four rounds of enrichment culture, culture broth was gradient diluted and spread on plates of Luria-Bertani, Czapek's, and Gause's solid media. After 1-d incubation under $37^{\circ} \mathrm{C}$ for bacteria and 3-d incubation under $30^{\circ} \mathrm{C}$ for fungi, 9 strains of bacteria and 17 strains of fungi were obtained. To test their ability in degrading chlorpyrifos, screened cultures were inoculated in $50 \mathrm{ml}$ MMC. After shaking under $30^{\circ} \mathrm{C}$ for $7 \mathrm{~d}$, the residue of chlorpyrifos was measured according to the method of Yu et al. (2006). MMC without cultures was used as a control. Each treatment was conducted three times.

\subsection{DNA sequence analysis for chlorpyrifos- degrading strains}

PCR products of primer pairs $8 \mathrm{~F} / 1492 \mathrm{R}$ for bacterial strains and ITS1f/ITS4 for fungal strains were ligated with vector pEASY-T4 (TransGen Biotech, China) and transformed into E. coli DH5 $\alpha$. This was verified by primer pair M13+/M13-, and three positive clones in each plate were selected for sequencing (Sangon, Shanghai, China). The sequences were analyzed with the BLAST program at the NCBI website (http://www.ncbi.nlm.nih.gov/blast). All genomic fragment sequences in this work were deposited in GenBank database under the accession numbers of JX966388, JX915245-JX915247, JX915250-JX915252, JX915254, and JX915255.

\subsection{Statistical analysis}

The banding patterns of DGGE and ERIC-PCR profiles were analyzed using the Quantity One V4.62 Software (Bio-Rad), and a binary matrix showing presence (1) and absence (0) of DGGE and ERIC-PCR bands was used. The Shannon-Wiener index $H$ was calculated by (da Mota et al., 2005)

$$
H=\sum_{i=1}^{S} P_{i} \ln P_{i}=-\sum_{i=1}^{S} \frac{N_{i}}{N} \ln \frac{N_{i}}{N}
$$

where $S$ is the observed number of bands and $P_{i}$ stand for the observed number of clones of a given species divided by the total number of organisms. Principal component analysis (PCA) of DGGE data was performed using MatLab (MathWorks). Cluster analysis of ERIC-PCR data was performed based on Dice's similarity coefficient (SD) with a $1 \%$ position tolerance and the unweighted pair group method using arithmetic averages (UPGMA), and isolates of more than $90 \%$ similarity were considered to be the same kind of isolate (Borges et al., 2003).

Each set of tests was repeated three times, and the results were averaged. Statistica software 5.5 was used for statistical data analysis. Least significant difference (LSD) multiple range test was considered to be significant when $P<0.05$. 


\section{Results}

\subsection{Degradation of chlorpyrifos in soil}

The degradation curve of chlorpyrifos in soil is shown in Fig. 1. Chlorpyrifos residues of 0.009 and $0.077 \mathrm{mg} / \mathrm{kg}$ were detected in the $60-\mathrm{d}$ samples of 5 and $20 \mathrm{mg} / \mathrm{kg}$ chlorpyrifos-treated soils, respectively. The dissipation of chlorpyrifos in soil followed the first-order kinetics, and the calculated half-lives of 5 and $20 \mathrm{mg} / \mathrm{kg}$ chlorpyrifos were 8.25 and $8.29 \mathrm{~d}$, respectively (Table 1 ).

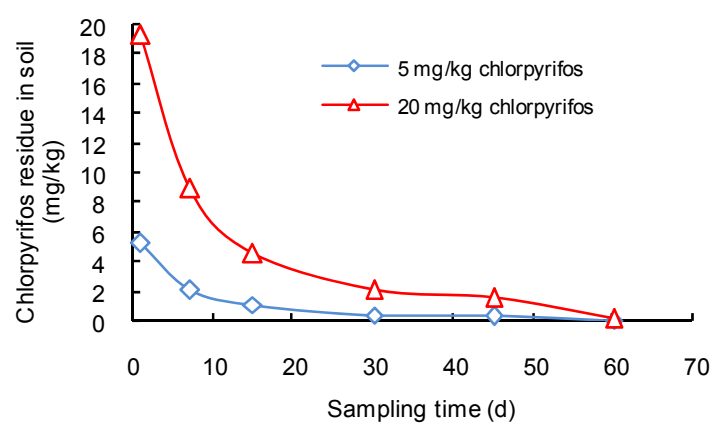

Fig. 1 Degradation of chlorpyrifos in soil

Table 1 Kinetics data of chlorpyrifos in soil

\begin{tabular}{cccc}
\hline $\begin{array}{c}\text { Chlorpyrifos } \\
\text { treatment }(\mathrm{mg} / \mathrm{kg})\end{array}$ & $\begin{array}{c}\text { Dynamic } \\
\text { function }\end{array}$ & $\begin{array}{c}\mathrm{DT}_{50} \\
(\mathrm{~d})\end{array}$ & $R^{2}$ \\
\hline 5 & $y=5.252 \mathrm{e}^{-0.09 x}$ & 8.25 & 0.910 \\
20 & $y=19.41 \mathrm{e}^{-0.08 x}$ & 8.29 & 0.908 \\
\hline
\end{tabular}

$\mathrm{DT}_{50}$ : half-life of chlorpyrifos in this experiment

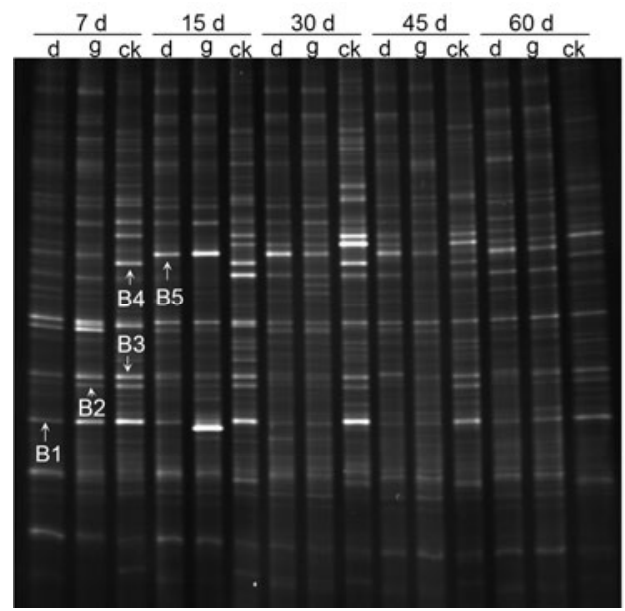

(a)

\subsection{Effects of chlorpyrifos on total bacterial and fungal communities in soil}

The PCR-DGGE banding profiles revealed clearly the dominant bacterial (Fig. 2a) and fungal (Fig. 2b) bands for each treatment. Most bands, like B1, B2, and B3, appeared in all samplings and only had a faint difference in intensity. Band B4 appeared only in the control, indicating that certain ribotype is suppressed by chlorpyrifos. Band B5 is common to the 15-, 30-, 45-, and 60-d samplings of chlorpyrifoscontaminated soils, but is missing in the 7-d sampling of chlorpyrifos-contaminated soil and all control sampling, suggesting that B5 ribotype proliferation needs a long-time chlorpyrifos stimulation. Band b1 first appeared only in the chlorpyrifos-treated soils in 7-, 15-, and 30-d samplings, while common to all treatments in 45- and 60-d samplings, the reasons for these observations are not clear. Some bands, like b2 and b3, are typical for all the chlorpyrifoscontaminated soils, indicating certain ribotypes are rapidly stimulated by chlorpyrifos and kept stable in soil. Band b4 appeared only in the 45- and 60-d samplings of chlorpyrifos-treated soil, suggesting that b4 ribotype might be stimulated by the 3,5,6trichloro-2-pyridinol (TCP), the main biodegradation product of chlorpyrifos.

Shannon-Wiener diversity indices (Table 2) showed that soil bacterial and fungal communities were impacted differently by the presence of

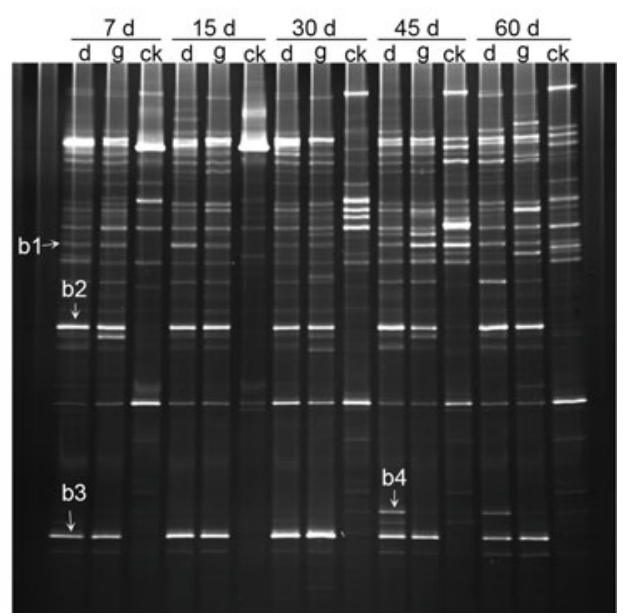

(b)

Fig. 2 DGGE community fingerprints of soil total bacteria (a) and fungi (b) in soil samples amended with chlorpyrifos at different sampling times

Lanes d, g, and ck stand for soil contaminated by chlorpyrifos of 5, 20, and $0 \mathrm{mg} / \mathrm{kg}$, respectively 
Table 2 Shannon-Wiener diversity indices of total bacterial and fungal communities under the stress of chlorpyrifos

\begin{tabular}{lcc}
\hline \multirow{2}{*}{ Sample $^{\mathrm{a}}$} & \multicolumn{2}{c}{ Shannon-Wiener index $H$} \\
\cline { 2 - 3 } & Bacterial community & Fungal community \\
\hline $\mathrm{d} 7$ & $3.68 \pm 0.12^{\text {cd }}$ & $3.35 \pm 0.03^{\mathrm{d}}$ \\
g7 & $3.56 \pm 0.04^{\mathrm{b}}$ & $3.30 \pm 0.04^{\mathrm{c}}$ \\
ck7 & $3.69 \pm 0.03^{\mathrm{cd}}$ & $3.06 \pm 0.02^{\mathrm{b}}$ \\
d15 & $3.66 \pm 0.05^{\mathrm{cd}}$ & $3.42 \pm 0.03^{\mathrm{fg}}$ \\
g15 & $3.48 \pm 0.04^{\mathrm{a}}$ & $3.39 \pm 0.02^{\mathrm{ef}}$ \\
ck15 & $3.62 \pm 0.02^{\mathrm{bc}}$ & $2.68 \pm 0.02^{\mathrm{a}}$ \\
$\mathrm{d} 30$ & $3.68 \pm 0.04^{\mathrm{cd}}$ & $3.43 \pm 0.02^{\mathrm{g}}$ \\
g30 & $3.88 \pm 0.06^{\mathrm{e}}$ & $3.29 \pm 0.02^{\mathrm{c}}$ \\
ck30 & $3.67 \pm 0.02^{\mathrm{cd}}$ & $3.53 \pm 0.02^{\mathrm{i}}$ \\
d45 & $3.96 \pm 0.01^{\mathrm{f}}$ & $3.54 \pm 0.02^{\mathrm{i}}$ \\
g45 & $4.02 \pm 0.05^{\mathrm{f}}$ & $3.34 \pm 0.01^{\mathrm{d}}$ \\
ck45 & $3.72 \pm 0.02^{\mathrm{d}}$ & $3.37 \pm 0.05^{\mathrm{de}}$ \\
d60 & $3.82 \pm 0.02^{\mathrm{e}}$ & $3.56 \pm 0.02^{\mathrm{i}}$ \\
g60 & $3.87 \pm 0.02^{\mathrm{e}}$ & $3.44 \pm 0.02^{\mathrm{gh}}$ \\
ck60 & $3.83 \pm 0.02^{\mathrm{e}}$ & $3.47 \pm 0.02^{\mathrm{h}}$ \\
\hline
\end{tabular}

${ }^{\mathrm{a}} \mathrm{d}$, g, and ck stand for soils contaminated by chlorpyrifos of 5 , 20 , and $0 \mathrm{mg} / \mathrm{kg}$, respectively; 7, 15, 30, 45, 60 stand for the sampling days after the chlorpyrifos treatment. Values are expressed as mean $\pm \mathrm{SD}$ of triplicate samples, means followed by the same letter within a column are not significantly different according to LSD's multiple range test $(P<0.05)$ chlorpyrifos. For the total bacterial community, $5 \mathrm{mg} / \mathrm{kg}$ chlorpyrifos treatment had a similar diversity index as the control, while $20 \mathrm{mg} / \mathrm{kg}$ chlorpyrifos had the lowest diversity indices except on Day 30 during the first $30 \mathrm{~d}$; diversity indices in all chlorpyrifostreated soil samples were higher than the control on Day 45 sampling, while getting similar to the control at the end of the experiment. For the total fungi community, diversity indices in chlorpyrifos-treated samples rose during the first $15-\mathrm{d}$ incubation and were slightly higher than that of the control. Subsequently, the diversity indices in the control samples rose on Day 30 and were higher than those of the treated samples. After 30-60 d of chlorpyrifos application, diversity indices in $5 \mathrm{mg} / \mathrm{kg}$ chlorpyrifos-treated samples were higher than that of the control, while the $20 \mathrm{mg} / \mathrm{kg}$ chlorpyrifos-treated samples had a similar diversity index as the control.

The PCA of the total bacterial community structure (Fig. 3a) showed that, during the first $30 \mathrm{~d}$ of chlorpyrifos application, whether 5 or $20 \mathrm{mg} / \mathrm{kg}$, the chlorpyrifos-treated samples were far apart from the control, especially on Day 7. The distance between the chlorpyrifos-treated samples and the control was getting shorter through time and clustered into one group on Day 60. This is probably because the soil bacteria had high tolerance and adaption to chlorpyrifos.

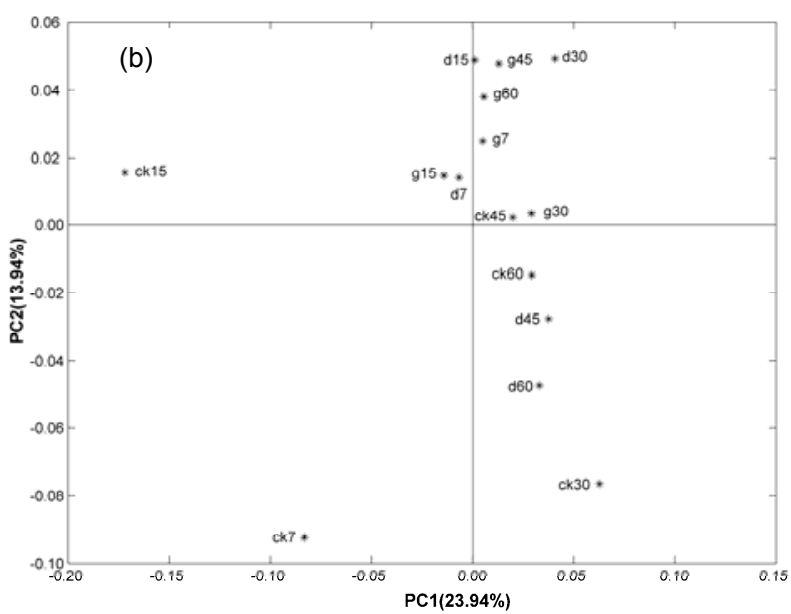

Fig. 3 PCA analysis of the soil total bacteria (a) and fungi (b) in soil samples amended with chlorpyrifos $\mathrm{d}$, g, and ck stand for soils contaminated by chlorpyrifos of 5, 20, and $0 \mathrm{mg} / \mathrm{kg}$, respectively; 7, 15, 30, 45, and 60 stand for the sampling days after the chlorpyrifos treatment. The values following the PC1 and PC2 in the axes stand for percentages of the first and second principal components to all components, respectively 
The fungal community as to whether 5 or $20 \mathrm{mg} / \mathrm{kg}$ chlorpyrifos-treated sample was far apart from the control during the first $30 \mathrm{~d}$ of chlorpyrifos application, which was in accordance with the changes in the bacterial community. While even though the diversity indices of total fungi in the $20 \mathrm{mg} / \mathrm{kg}$ chlorpyrifos-treated samples were similar to that of the control on Day 60, the population structures of the chlorpyrifos-treated samples did not recover to the control level as indicated by the PCA analysis (Fig. 3b). The result indicates that soil fungal community was affected rapidly and persistently under the stress of chlorpyrifos.

\subsection{Isolation of chlorpyrifos-degrading strains and ERIC-PCR analysis}

Twelve fungal strains ( 8 from Czapek's medium, named CR9, CR10, CR12, CR4, CR13, CR11, CR1, and CR14; 4 from Gause's medium, named GR2, GR4, GR3, and GR1) and two bacterial strains (from Luria-Bertani medium, named LR4 and LR5) were isolated from the chlorpyrifos-treated soils, and they could degrade more than $80 \%$ of chlorpyrifos after 7 -d cultivation (Table 3 ), while only a $23.14 \%$ degradation rate was observed in the control.

Table 3 Chlorpyrifos degradation rates of strains isolated from chlorpyrifos-treated soils after 7-d cultivation

\begin{tabular}{ccc}
\hline Medium & Clone No. & Degradation rate (\%) \\
\hline Czapek's & CR1 & $92.47 \pm 0.90^{\mathrm{gh}}$ \\
& CR4 & $87.98 \pm 1.54^{\mathrm{de}}$ \\
& CR9 & $97.54 \pm 2.02^{\mathrm{i}}$ \\
& CR10 & $91.54 \pm 1.71^{\mathrm{g}}$ \\
& CR11 & $94.11 \pm 1.72^{\mathrm{h}}$ \\
& CR12 & $87.16 \pm 0.80^{\mathrm{de}}$ \\
& CR13 & $82.85 \pm 1.23^{\mathrm{bc}}$ \\
& CR14 & $91.68 \pm 1.00^{\mathrm{g}}$ \\
Gause's & GR1 & $82.02 \pm 0.49^{\mathrm{b}}$ \\
& GR2 & $83.22 \pm 1.74^{\mathrm{bc}}$ \\
& GR3 & $84.49 \pm 0.74^{\mathrm{c}}$ \\
Luria-Bertani & GR4 & $86.86 \pm 1.09^{\mathrm{d}}$ \\
& LR4 & $90.44 \pm 1.19^{\mathrm{fg}}$ \\
Control & LR5 & $89.16 \pm 1.33^{\mathrm{ef}}$ \\
\hline
\end{tabular}

All values are mean $\pm \mathrm{SD}$ of triplicate samples, means followed by the same letter within a column are not significantly different according to LSD multiple range test $(P>0.05)$
The electrophoresis prowls of ERIC-PCR products were determined for the 14 chlorpyrifosdegrading isolates. The data matrix based on the DNA fragments was constructed. As shown in the ERICPCR fingerprint of isolates (Fig. 4), the similarities for LR4 and LR5, GR4 and CR13, GR2 and CR12, GR1 and GR3, and CR1 and CR14 reached above $90 \%$. Isolates of more than $90 \%$ similarity in the ERIC-PCR fingerprint were treated as the ERIC type, so all the chlorpyrifos-degrading isolates obtained in this study were grouped into nine different ERIC types based on the ERIC-PCR pattern similarity.

The PCR products of $8 \mathrm{~F} / 1492 \mathrm{R}$ for ERIC-I and ITS1f/ITS4 for ERIC-II to -IX were ligated with vector $\mathrm{pEASY}-\mathrm{T} 4$ and transformed into E. coli $\mathrm{DH} 5 \alpha$. Sequences of the nine representative ERIC types were obtained (Table 4), further BLAST analysis demonstrated that clones of ERIC-I type showed a 99\% similarity to Bacillus cereus, clones of ERIC-II, -III, and -IV types were of $100 \%$ similarities to Fusarium sp.; clones of ERIC-V, -VII, and -VIII showed 99\%, $100 \%$, and $100 \%$ similarities to Gibberella moniliformis, respectively; clones of ERIC-VI type showed a 95\% similarity to Dipodascaceae sp.; and, clones of ERIC-IX type showed a $100 \%$ similarity to Chaetomium globosum.

\section{Discussion}

In this study, the degradation of chlorpyrifos shows the first-order kinetic characteristics with the determination coefficient of more than 0.9 , which is in agreement with the dissipation of chlorpyrifos in most soil types (Devashis and Ramen, 2005; Fang et al., 2008; 2009). While sometimes the first-order kinetics is not satisfactory for the description of chlorpyrifos in soil, it can be better described by the biexponential model (Fang et al., 2006; Chu et al., 2008). This may be due to different soil environments and soil microorganisms.

DGGE fingerprinting and further PCA obtained in this study with soil DNA show shifts in the composition of dominant bacterial and fungal populations in different time after the application of chlorpyrifos to soil. The experimental results indicate that the 


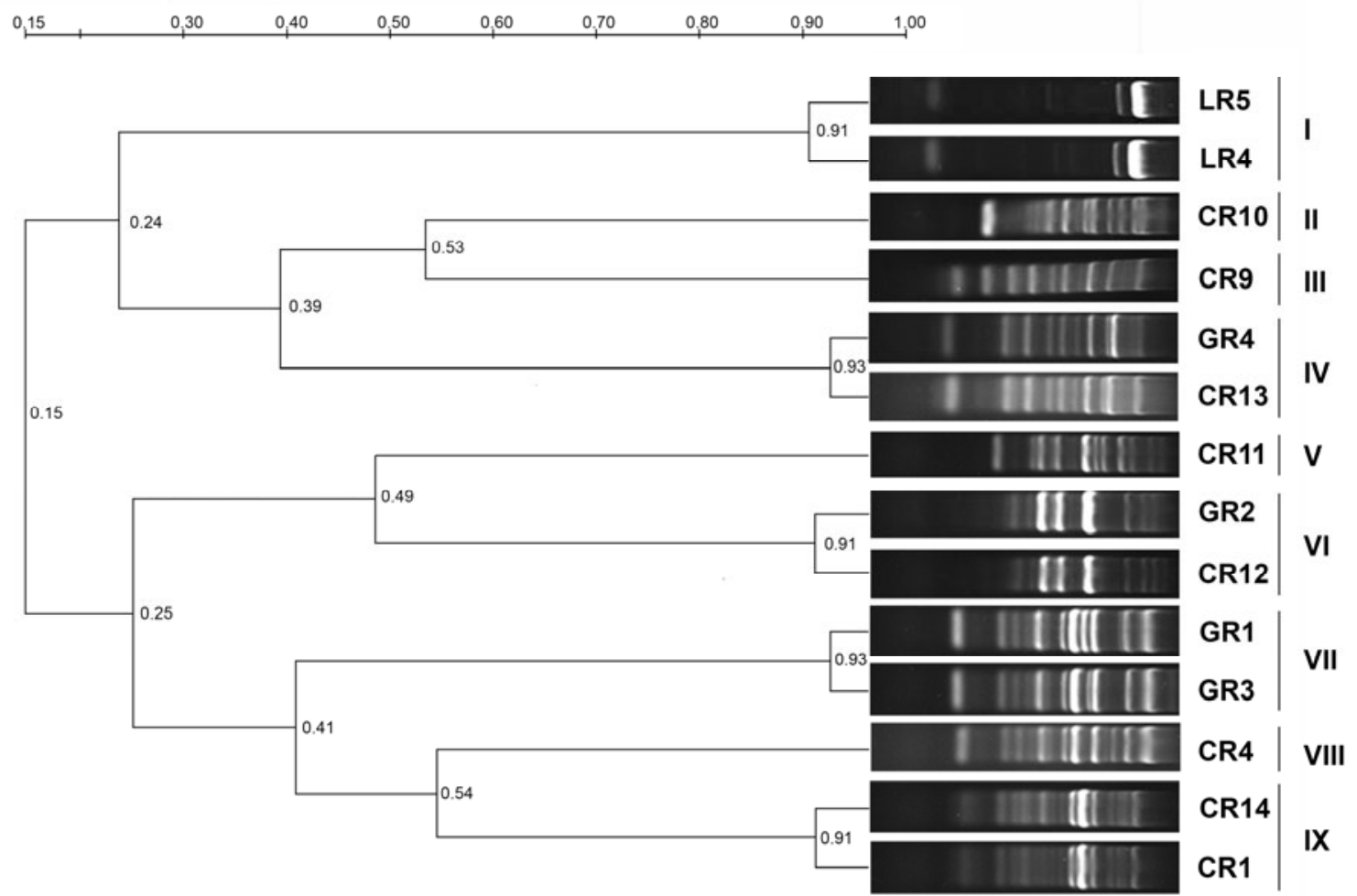

Fig. 4 ERIC-PCR fingerprints of 14 chlorpyrifos-degrading strains

I-IX stand for ERIC types of chlorpyrifos-degrading strains

Table 4 Species of clones with ITS sequence for fungi and 16S rDNA sequence for bacteria in NCBI GenBank database most similar to the nine ERIC types of chlorpyrifos-degrading strains

\begin{tabular}{lllcc}
\hline \multirow{2}{*}{$\begin{array}{c}\text { ERIC } \\
\text { type }\end{array}$} & \multirow{2}{*}{ Clone No. } & \multicolumn{2}{c}{ Closest match from GenBank } & \multirow{2}{c}{$\begin{array}{c}\text { GenBank } \\
\text { accession No. }\end{array}$} \\
\cline { 3 - 4 } I & LR4, LR5 & Macillus cereus & Sequence similarity by BLAST (\%) & JX966388 \\
II & CR10 & Fusarium sp. & 99 & JX915255 \\
III & CR9 & Fusarium oxysporum & 100 & JX915246 \\
IV & GR4, CR13 & Fusarium sp. & 100 & JX915247 \\
V & CR11 & Gibberella moniliformis & 100 & JX915252 \\
VI & CR12, GR2 & Dipodascaceae sp. & 99 & JX915245 \\
VII & GR3, GR1 & Gibberella moniliformis & 100 & JX915251 \\
VIII & CR4 & Gibberella moniliformis & 100 & JX915250 \\
IX & CR1, CR14 & Chaetomium globosum & 100 & JX915254 \\
\hline
\end{tabular}

application of chlorpyrifos at the recommended or four times dose to soil can affect the soil fungal community rapidly and persistently, while the bacterial community is significantly $(P<0.05)$ different in the first $30 \mathrm{~d}$ and recovers to a similar level to the control until $60 \mathrm{~d}$. Results from our studies are somewhat different from those of Chu et al. (2008), which reported that the populations of bacteria, fungi, and actinomycetes were significantly reduced by $44.1 \%, 61.1 \%$, and $72.8 \%$, respectively, on the first 
day after treatment by chlorpyrifos at the recommended dose and recovered to a similar level of the control until $14 \mathrm{~d}$ using the plate counting method. The responses of the dominant bacterial and fungal community structures are different from culturable and countable bacterial and fungal populations, probably because the culturable and countable microbes are only a minor part of total microbes in soil. Recovery of microbial quantity in soil only showed some microbes adapted to the existence of chlorpyrifos have been rapidly proliferated. Therefore, recovery in numbers of culturable microbes does not stand for the recovery in the community structure. To some extent, the number of culturable microbes may be associated with soil functions, because the study relied on the biology method (Fang et al., 2009) shows that the average well color development in soils is significantly $(P<0.05)$ inhibited by chlorpyrifos in the first two weeks and thereafter recovers to a similar level as the control. A similar variation in the diversity indices (Simpson index $1 / D$ and McIntosh index $U$ ) is observed, but no significant difference among the values of the Shannon-Wiener index $H$ was found in chlorpyrifos-treated soils (Fang et al., 2009). In the same time, Wang et al. (2010) found that microbial metabolic parameters (growth rate constant $k$, total heat evolution $Q_{\mathrm{T}}$, metabolic enthalpy $\Delta H_{\text {met }}$, mass specific heat rate $J_{\mathrm{Q} / \mathrm{S}}$, microbial biomass $C$, and inhibitory ratio $I$ ) and urease activity almost keep constant when exposed to chlorpyrifos $(<5.0 \mathrm{mg} / \mathrm{kg})$. Therefore, it is concluded that the soil microbial function can keep stable by shifting resources from other biological activities (such as reproduction or growth) toward survival to some extent. We can see that a combination of different methods can give a more comprehensive analysis of chlorpyrifos effects on soil ecology.

Nine typical ERIC types of chlorpyrifosdegrading isolates were screened from chlorpyrifostreated soil, which showed high similarity to Bacillus cereus, Fusarium sp., Gibberella moniliformis, Dipodascaceae sp., and Chaetomium globosum, respectively by DNA BLAST in GenBank database. Among them, Bacillus cereus (Vidya et al., 2009) and Fusarium sp. (Xie et al., 2010) had been reported for their ability of degrading chlorpyrifos, while Gibbe- rella moniliformis, Dipodascaceae sp., and Chaetomium globosum were first reported in public literature. Robertson et al. (1998) found that rapid loss of chlorpyrifos is more likely to occur at sites where the chlorpyrifos has been applied in previous crop cycles, compared to sites where there has been no prior use. The rcommon opinion was that microbial degradation has contributed to rapid loss of chlorpyrifos. Biodegradation using native microorganisms is considered to be a safe, cost-effective, efficient, and eco-friendly method. Therefore, it is necessary to isolate different kinds of strains for bioremediation of chlorpyrifoscontaminated soil under different soil types and climatic conditions.

\section{Conclusions}

At the end of the microcosm experiment $(60 \mathrm{~d}$ after chlorpyrifos application), chlorpyrifos-treated soil samples and the control ad a similar diversity index, and were clustered into one group in PCA for the total bacterial community; for the total fungal community, even though the diversity indices in chlorpyrifos-treated soil samples was similar to that of the control, the population structures of chlorpyrifos-treated samples did not recover to the control. Our data show that chlorpyrifos applications can affect fungal community structures in a quick and lasting way, while only affecting the bacterial community in a temporary way. Finally, 14 typical chlorpyrifos-degrading isolates were screened and classified into 9 ERIC types, which showed high similarities to Bacillus cereus, Fusarium sp., Gibberella moniliformis, Dipodascaceae sp., and Chaetomium globosum, respectively, by DNA BLAST in GenBank database.

\section{Acknowledgements}

We sincerely express our thanks to Dr. Xin WANG (Institute of Plant Protection and Microbiology, Zhejiang Academy of Agricultural Sciences, China) for his help in analyzing the community structure.

\section{Compliance with ethics guidelines}

Lie-zhong CHEN, Yan-li LI, and Yun-long YU declare that they have no conflict of interest. 
This article does not contain any studies with human or animal subjects performed by any of the authors.

\section{References}

Anwar, S., Liaquat, F.M., Khan, Q.M., et al., 2009. Biodegradation of chlorpyrifos and its hydrolysis product 3,5,6-trichloro-2-pyridinol by Bacillus pumilus strain C2A1. J. Hazard. Mater, 168(1):400-405. [doi:10.1016/ j.jhazmat.2009.02.059]

Borges, L.G.D., Dalla, V.V., Corçao, G., 2003. Characterization and genetic diversity via REP-PCR of Escherichia coli isolates from polluted waters in southern Brazil. FEMS Microb. Ecol., 45(2):173-180. [doi:10.1016/S0168-6496 (03)00147-8]

Chu, X.Q., Fang, H., Pan, X.D., et al., 2008. Degradation of chlorpyrifos alone and in combination with chlorothalonil and their effects on soil microbial populations. $J$. Environ. Sci., 20(4):464-469. [doi:10.1016/S1001-0742 (08)62080-X]

da Mota, F.F., Gomes, E.A., Paiva, E., et al., 2005. Assessment of the diversity of Paenibacillus species in environmental samples by a novel rpoB-based PCR-DGGE method. FEMS Microbial. Ecol., 53(2):317-328. [doi: 10.1016/j.femsec.2005.01.017]

Devashis, S., Ramen, K.K., 2005. Metabolism of chlorpyrifos in relation to its effect on the availability of some plant nutrients in soil. Chemosphere, 61(9):1273-1280. [doi: 10.1016/j.chemosphere.2005.03.078]

Fang, H., Yu, Y.L., Wang, X.G., et al., 2006. Dissipation of chlorpyrifos in pakchoi-vegetated soil in a greenhouse. $J$. Environ. Sci., 18(4):760-764.

Fang, H., Yu, Y.L., Wang, X.G., et al., 2008. Effects of repeated applications of chlorpyrifos on its persistence and soil microbial functional diversity and development of its degradation capability. Bull. Environ. Contam. Toxicol., 81(4):397-400. [doi:10.1007/s00128-008-9514-6]

Fang, H., Yu, Y.L., Chu, X.Q., et al., 2009. Degradation of chlorpyrifos in laboratory soil and its impact on soil microbial functional diversity. J. Environ. Sci., 21(3): 380-386. [doi:10.1016/S1001-0742(08)62280-9]

Gillings, M., Holley, M., 1997. Repetitive element PCR fingerprinting (rep-PCR) using enterobacterial repetitive intergenic consensus (ERIC) primers is not necessarily directed at ERIC elements. Lett. Appl. Microbiol., 25(1): 17-21. [doi:10.1046/j.1472-765X.1997.00162.x]

Kulkarni, A.R., Soppimath, K.S., Dave, A.M., et al., 2000. Solubility study of hazardous pesticide (chlorpyrifos) by gas chromatography. J. Hazard Mater, 80(1-3):9-13. [doi:10.1016/S0304-3894(00)00276-4]

Li, X.Y., Zhang, H.W., Wu, M.N., et al., 2008. Effect of methamidophos on soil fungi community in microcosms by plate count, DGGE and clone library analysis. J. Environ. Sci., 20(5):619-625. [doi:10.1016/S1001-0742(08) 62210-X]

Maya, K., Singh, R.S., Upadhyay, S.N., et al., 2011. Kinetic analysis reveals bacterial efficacy for biodegradation of chlorpyrifos and its hydrolyzing metabolite TCP. Process. Biochem., 46(11):2130-2136.

Muyzer, G., de Waal, E.C., Uitterlinden, A.G., 1993. Profiling of complex microbial populations by denaturing gradient gel electrophoresis analysis of polymerase chain reaction-amplified genes coding for $16 \mathrm{~S}$ ribosomal RNA. Appl. Environ. Microbiol., 59(3):695-700.

Pandey, S., Singh, D.K., 2006. Soil dehydrogenase, phosphomonoesterase and arginine deaminase activities in an insecticide treated groundnut (Arachis hypogaea L.) field. Chemosphere, 63(5):869-880. [doi:10.1016/j. chemosphere.2005.07.053]

Robertson, L.N., Chandler, K.J., Stickley, B.D.A., et al., 1998. Enhanced microbial degradation implicated in rapid loss of chlorpyrifos from the controlled-release formulation suSCon ${ }^{\circledR}$ Blue in soil. Crop. Prot., 17(1):29-33. [doi:10. 1016/S0261-2194(98)80009-4]

Sampaio, J.L.M., Viana-Niero, C., de Freitas, D., et al., 2006. Enterobacterial repetitive intergenic consensus PCR is a useful tool for typing Mycobacterium chelonae and Mycobacterium abscessus isolates. Diagn. Microbiol. Infect. Dis., 55(2):107-118. [doi:10.1016/j.diagmicrobio. 2006.01.006]

Sardar, D., Kole, R.K., 2005. Metabolism of chlorpyrifos in relation to its effect on the availability of some plant nutrients in soil. Chemosphere, 61(9):1273-1280.

Sebiomo, A., Ogundero, V.W., Bankole, S.A., 2011. Effect of four herbicides on microbial population, soil organic matter and dehydrogenase activity. Afr. J. Biotechnol., 10(5):770-778.

Valášková, V., Baldrian, P., 2009. Denaturing gradient gel electrophoresis as a fingerprinting method for the analysis of soil microbial communities. Plant Soil Environ., 55(10):413-423.

Vidya, L.C., Kumar, M., Khanna, S., 2009. Biodegradation of chlorpyrifos in soil by enriched cultures. Curr. Microbiol., 58(1):35-38. [doi:10.1007/s00284-008-9262-1]

Wang, F., Yao, J., Chen, H.L., et al., 2010. Comparative toxicity of chlorpyrifos and its oxon derivatives to soil microbial activity by combined methods. Chemosphere, 78(3):319-326. [doi:10.1016/j.chemosphere.2010.06. 052]

Xie, H., Zhu, L.S., Ma, T.T., et al., 2010. Immobilization of an enzyme from a Fusarium fungus WZ-I for chlorpyrifos degradation. J. Environ. Sci., 22(12):1930-1935. [doi: 10.1016/S1001-0742(09)60341-7] 
Yu, Y.L., Fang, H., Wang, X., et al., 2006. Characterization of a fungal strain capable of degrading chlorpyrifos and its use in detoxification of the insecticide on vegetables. Biodegradation, 17(5):487-494. [doi:10.1007/s10532005-9020-z]
Yuan, W., Chai, T.J., Miao, Z.M., 2010. ERIC-PCR identification of the spread of airborne Escherichia coli in pig houses. Sci. Total. Environ., 408(6):1446-1450. [doi:10. 1016/j.scitotenv.2009.12.019]

\section{中文嘫要:}

本文题目: 毒死蜱胁迫下土壤细菌和真菌群落演替及其降解菌群的分子鉴定

Soil bacterial and fungal community successions under the stress of chlorpyrifos application and molecular characterization of chlorpyrifos-degrading isolates using ERIC-PCR

研究目的：评价毒死蜱施用后对土壤细菌和真菌群落结构的影响, 并对降解功能菌株进行分析。

创新要点: 通过聚合酶链式反应一变性梯度凝胶电泳（PCR-DGGE）方法, 揭示了毒死蜱施用后土壤 细菌和真菌群落结构动态变化, 并对试验土壤中的降解菌群进行分子鉴定。

研究方法: 将农田土壤用终质量分数 $5 \mathrm{mg} / \mathrm{kg}$ 和 $20 \mathrm{mg} / \mathrm{kg}$ 毒死蜱处理, 同时以不施用毒死蜱为对照, 定期采集土样进行毒死蜱残留测定并提取土壤 DNA。将提取的土壤总 DNA 作为 PCR 反应 模板，细菌群落结构分析采用对大多数细菌 16S rRNA 基因 V3 区具有特异性的引物 GC-341F 和 517R, 真菌群落结构分析采用 ITS 区特异引物对 GC-ITS1f 和 ITS2f。DGGE 图谱经 Quantity One 软件进行数字化分析, 各泳道中的条带经标准化处理之后, 条带的相 对光密度构成一个矩阵, 用 Matlab 软件进行主成分分析（PCA），用 Dice 法计算相似性 指数 CS, 用 MEGA 4.1 软件构建系统发育树, 进行聚类分析。之后, 采用 LB、察氏和高 氏三种培养基结合的纯培养分离方法, 从毒死蜱处理土样中分离具有降解功能的菌株。分 别提取纯培养物的染色体 DNA, 利用 ERIC-PCR 对分离到的降解菌进行基因组指纹图谱分 析，将典型肠杆菌基因间的重复共有序列-聚合酶链式反应（ERIC-PCR）指纹图谱类型的 代表菌株进行 16S rRNA 基因（细菌和放线菌）或 ITS 区（真菌）扩增并测序，测序结果 提交 GenBank 基因库, 并进行 BLAST 比对, 初步确定降解菌株的分子地位。

重要结论: 本实验条件下, 毒死蜱降解符合一级动力学, $5 \mathrm{mg} / \mathrm{kg}$ 和 $20 \mathrm{mg} / \mathrm{kg}$ 毒死蜱浓度下的降解方 程分别为 $y=5.252 \mathrm{e}^{-0.09 x}$ 和 $y=19.41 \mathrm{e}^{-0.08 x}$ 。DGGE 指纹图谱显示, 毒死蜱施用后土壤真菌群 落结构与对照相比发生很大改变, 且毒死蜱处理样品真菌群落结构保持基本稳定, 多样性 指数明显提高（见图 $2 b$ ）；主成分分析显示, 毒死蜱处理样品与对照明显分在 2 个不同的 区域, 充分表明毒死蜱对土壤真菌群落结构影响迅速且持久（见图 3b）。毒死蜱处理样品 细菌群落结构只在试验前 30 天与对照相比明显不同, 60 天时已经恢复对照水平 (见图 2a), 同时主成分分析图上，毒死蜱处理样品与对照也越来越靠近，最后聚在一起（见图 3a）, 说明毒死蜱对土壤细菌群落结构影响短暂。最后, 获得了 9 个典型的 ERIC 型毒死蜱降解 菌株。

关键词组: 变性梯度凝胶电泳 (DGGE) ; 细菌群落结构; 真菌群落结构; 毒死蜱降解菌群; ERIC-PCR 